БЪЛГАРСКА АКАДЕМИЯ НА НАУКИТЕ

ИЗВЕСТИЯ НА ИНСТИТУТА ЗА БЪЛГАРСКИ ЕЗИК „ПРОФ. ЛЮБОМИР АНДРЕЙЧИН“

Кн иг а XXXIV

\author{
МОТИВИ ЗА ТЬРСЕНЕ НА СПЕЦИАЛИЗИРАНА \\ ЕЗИКОВЕДСКА ПОМОЩ \\ (ИЗ ПРАКТИКАТА НА ЕЗИКОВОТО КОНСУЛТИРАНЕ)
}

\author{
Милен Томов \\ Институт за български език, БАН
}

\title{
REASONS FOR SEEKING SPECIALIZED LINGUISTIC ASSISTANCE (FROM THE EXPERIENCE OF LANGUAGE COUNSELLING)
}

\author{
Milen Tomov \\ Institute for Bulgarian Language, Bulgarian Academy of Sciences
}

Резюме: Обект на изследване в настоящата работа са разнообразните мотиви за използване на услугата езикови справки и консултации. Извършеният анализ показва, че зад всички тези мотиви като централен изходен пункт стои стремежът към нормосъобразно изразяване, към правилна езикова употреба, породен от схващането на книжовния език и грамотността като ценност и като средство за повишаване на личния и обществения престиж и белег на висок професионализъм. Всички разгледани мотиви за търсене на специализирана езиковедска помощ разкриват реалните условия, при които функционира книжовният език.

Ключови думи: езиково консултиране, мотиви за тьрсене на езиковедска помощ, езикови колебания, Служба за езикови справки и консултации

Abstract: The subject of research in this paper are the various motives for using the service language information and counselling. The analysis carried out shows that striving for proper normative expression, for correct language use driven by the perception of Standard Language and literacy as a value and means for enhancing personal and public prestige and a sign for high professionalism lies behind all these motives as a central starting point. All the reasons for seeking specialised linguistic help examined reveal the real conditions under which the Standard Language functions.

Keywords: language counselling, reasons for seeking llinguistic assistance, language hesitations, Language Consultations Service 
Дългогодишното съществуване и функциониране на Службата за езикови справки и консултации към Института за български език при БАН свидетелства за очевидното наличие на постоянна реално сыществуваща необходимост от професионална помощ при проблемни езикови случаи ${ }^{1}$. Все по-големият интерес към услугата езиково консултиране говори за нарастващата потребност на езиковата общност от такъв вид експертна инстанция, която да предоставя езикови съвети и информация и да гарантира сигурност при възникващи колебания в употребата на езика. Всеки жив език съдържа случаи на вариантност, колебания и неустановеност като резултат от непрекъснатото езиково развитие и изменение, които предизвикват трудности при употребата му в практиката и най-вече при прилагането на книжовноезиковите правила. Във връзка с това в досегашните теоретични изследвания в областта на езиковото консултиране на преден план стоят преди всичко класификацията, лингвистичният и количественият анализ на задаваните выпроси, като се правят заключения относно процесите на езиковите промени и се определят пунктовете в нормативната система, които изискват кодификаторска намеса или най-малкото - изострено внимание от страна на езиковедите нормализатори (Димитрова/Dimitrova 2005; Томов/Tomov 2006; Чаралозова, Станчева/Charalozova, Stancheva 2006, Мониторинг/Monitoring 2020 и др.). По-рядко, в мальк брой публикации, се разкриват ситуацията и обстоятелствата, при които протича диалогьт между езиковеда и потребителя на информация (Костадинова/Kostadinova 1996, Паскалев/Paskalev 2006, Томов/Tomov 2017). Самите мотиви за търсене на специализирана езиковедска помощ досега не са били обект на специален изследователски интерес.

Службата за езикови справки и консултации при Института за български език има дългогодишна история и през десетилетията на своето съществуване е натрупала уникален по своя характер масив от езикови въпроси и отговори. Звеното разполага с уникален по рода си материал - реални потребителски въпроси и техните отговори, свързани с различни аспекти на функциониране на българския език, и най-вече на книжовния език в неговата устна и писмена форма в различни сфери на комуникация. До този момент архивите са използвани от специалистите в Секцията за съвременен български език преди всичко за идентифициране на затрудненията при прилагането на книжовноезиковите правила с оглед на кодификаторската дейност. Преместването на езиковото консултиране в интернет среда и разкриването на нови канали за контакт с езиковата общност (Томов, Кунева/Tomov, Kuneva 2018; Чаралозова и др./Charalozova et al. 2017) разширява кръга от възможности за научни изследвания върху теорията и практиката на езиковото консултиране. Така в рамките на проекта Езикова култура и езикова политика. Електронни ресурси за езикови консултачии, раз-

1 Чрез дейността на Службата Институтьт за български език осъществява последователно своята консултантска и експертна дейност в областта на езиковата култура в тясна връзка с функциите на книжовния език и с практическите аспекти на кодификацията. 
работван в Секцията за съвременен български език, с изследователска цел бяха използвани възможностите за електронно архивиране на езиковите въпроси и отговори, както и опитът при разработването на справочника „Езикови справки по интернет“, които обогатяват съществуващите до този момент източници на езикова и социолингвистична информация за състава, езиковото поведение и нагласи на питащите (отделни лица, преподаватели, журналисти, писатели и преводачи, административни служители, държавни служби и органи на властта, бизнес организации, издатели и коректори и т.н.). Чрез електронното архивиране на езиковите справки и чрез фиксирането на въпросите и отговорите в интернет справочника комуникацията между езиковеда и потребителя става още по-явна, тъй като се дава възможност много по-лесно да се съхраняват и използват в теоретичните езиковедски изследвания не само зададените въпроси, но и придружаващите ги уводни и заключителни разговори и коментари, което позволява едно много по-адекватно и надеждно наблюдение върху потребителското поведение и нагласи и следователно води до правенето на по-точни изводи относно мотивите за търсене на специализирана езиковедска помощ, които са обект на настоящата работа. Анализиран е материал от последните 2 години, като се взема предвид и дълготрайността на проблематиката в практиката на езиковото консултиране ${ }^{2}$ (Томов/Tomov 2016a).

\section{Осъзнаване на езиковия проблем и усещане на колебание или затруднение}

Преди да пристъпим към разглеждането на отделните мотиви, ще се спрем по-общо и принципно на въпроса кога и как възниква чувството за езиково затруднение или колебание. Мотивите за търсене на специализирана езиковедска помощ, т.е. поводите потребителите да се обръщат с въпроси към Службата за езикови справки и консултации, могат да бъдат доста разнообразни. Както ще бъде показано по-нататък, езикови консултации се искат преди всичко тогава, когато са налице колебания при употребата на езика или несигурност в прилагането на езиковите правила. В повечето случаи потребителите на Службата притежават изострено езиково чувство - в противен случай те изобщо не биха осъзнали и установили дадения езиков проблем и у тях не би възникнало усещането за съмнение или несигурност, което да ги подтикне към търсене на помощ от специалист. Разнообразните запитвания, които са документирани от Службата за езикови справки и консултации, както и поддържането на другите форми на езиково консултиране (езикови бележки, специализирани публикации, участия в радио- и телевизионни предавания, различни интернет сайтове за езиково консултиране и др.под.) свидетелстват именно за постоянно усещане

2 При публикуването на резултатите от изследването се запазва анонимността на потребителите, отправили съответните запитвания. 
за несигурност или колебание у носителите на езика в реалната практика. У говорещите възниква усещането, че нещо не е наред, че нещо не е вярно или че някакво определено място в текста не е оптимално добре оформено. Такова усещане може да се породи както при продукция на собствен текст, така и при рецепция на чужд текст. В процеса на езиковото общуване потребителят забелязва у себе си или у другите някакъв непознат или необичаен израз или форма, която му се струва особена, или се натъква на някаква езикова употреба, която му изглежда проблемна или необичайна, или открива някаква грешка в текста. Когато не може да намери сам информация за езиковото явление или се чувства несигурен в собствените си знания, той се обръща към езиков специалист (консултант), който да му помогне: Здравейте. Редактирам книгата ми и ме интересува дали пунктуацията е спазена в тези 3 изречения; С колеги имаме колебание относно правилната пунктуация в няколко изречения; ... Така ли е, или аз греша?; Бих искала да попитам кой от двата текста е правилно изписан и защуо; През последните няколко години наблюдавам голямо разнообразие в изписването на имената на различни училища...; Искам да попитам как се пише „Въоръжените сили на Република България“" или „въоръжените сили на Република България “- с малка или с голяма буква. В различни държавни документи го срещам и по двата начина; Имам въпрос относно точното название на страната Гвиана. В сайта на МВнP https://www.mfa.bg/bg/embassyinfo/ guуапа са употребени два варианта - Гвиана и Гаяна. Може ли да кажете каква е нормата?; Моля да потвърдите правилното изписване на думата „импрегнант“. Срещуам често „импрегнатор “, в други случаи, продуктите за импрегнация са наречени „импрегнанти“. Кое е правилното изписване - „импрегнант“ или „импрегнатор"?; Отново Ви пиша с молба за разяснение на казус, на който попаднах. ... Интересно ми е каква би могла да е причината да изписват и в двата случая запетая преди тирето. Правилно ли е изобщо?; Благодаря много. И аз така мислех, но сега вече съм сигурна! Обвиняват ме, че слагам много запетаи, затова питам; Как се съкращават ,бележка на редактора/автора/преводача"? В интернет се намират съкратени по различен начин - б.а., б.авт., бел. авт.; На различни места Захари е написано различно в Уикипедия с -ий, същзо и в името на издателство ,,Захарий Стоянов“, но в различни издания на „Записки по българските въстания“- Захари Стоянов; Изречението ми изглежда странно без запетая и при произнасяне - без пауза; Чудя се дали запетаята пред „, особено “ би била смислоразличителна.

Както се вижда от изведените примери, доста от запитванията са породени от забелязано разнообразие при определени случаи в езиковата практика - в интернет, в медиите, в специализираната или художествената литература и пр.

Тъй като повечето от конкретните мотиви за търсене на езиковедска помощ заслужават специално изследователско внимание във връзка с теорията и най-вече с практиката на езиковото консултиране, по-нататък ще се спрем поотделно на по-често срещаните от тях. 


\section{1. Неумение или нежелание за ползване на справочници; липса на опит за ползване на справочници и за ориентация в езиковите правила}

Характерьт на някои запитвания свидетелства за това, че част от обаждащите се в Службата за езикови справки и консултации нямат опит с използването на различните речници на българския език, въпреки че знаят за съществуването на определени справочници в книжна форма, както и за тяхната достьпност на интернет страницата на Института за български език, но не смеят или не желаят да ги използват.

Встьпителните разговори с дежурния езиковед ясно показват, че немалка част от обаждащите се вече сами са опитали да си помогнат да разрешат съответния езиков проблем, като са прибягнали до някакъв справочник (независимо дали става въпрос за традиционно или онлайн издание), но не са се справили достатъчно добре с ориентирането си в него. От друга страна, някои потребители не умеят да се ориентират добре в самите правила за употреба на книжовния език, изложени по определен начин в справочниците. Това означава, че използването на справочници, т.е. търсенето и намирането на решение на даден проблем в тях, се смята от много хора за трудно. Причината би могла да бъде не само в липсата на опит при боравенето със справочници и граматики, но също и в самата концепция и структура на съответния справочник. ${ }^{3}$

В други случаи, обратно, обаждащите се изобщо не разполагат с речници, граматики или други справочници, така че идентифицираният езиков проблем веднага поражда необходимост от обаждане на Службата за езикови справки. Някои потребители пък изобщо не желаят да направят ни най-малко усилие за проверка в справочник. Те също посягат с готовност направо към телефона, което показва стремеж да се получи информация по най-бърз и лесен начин и наготово, и то, така да се каже, „от първа ръка“. Друг фактор освен невъзможността самостоятелно да се намери решение на езиковия проблем е липсата на време.

\section{2. Невъзможност на наличните справочници и граматики да дадат отговор на възникналия въпрос}

В някои случаи повод за обаждане в Службата за езикови справки и консултации е недостатьчната или противоречива информация в наличните справочници и граматики, която затруднява възможността да се открие отговор на въпроса и съответно да се стигне до разрешение на възникналия проблем. Тук Службата за езикови справки често поема функцията не само на компетентен езиков партньор, чиято дейност е насочена към подобряване на качеството на

${ }^{3}$ Това означава, че би било полезно в рамките на училищното обучение по български език да се включи работа с различните видове езикови речници и най-вече с достъпните онлайн справочници за българския език (тълковен речник, интернет справочник „Езикови справки“ и др.). 
езиковата употреба, но и на своего рода арбитър. Важно е обаче по този повод да отбележим, че кодификацията сама по себе си не е в състояние да даде експлицитен отговор на всички конкретни въпроси, възникващи при прилагането на правилата, и нейният обхват не е тотален. Освен това съществуват по-слабо регламентирани сфери, както и сфери, които по принцип трудно се поддават на регламентация. В такива ситуации потребителите се чувстват неудовлетворени от съществуващата в справочниците информация или изобщо от нейната липса. Истински проблеми възникват именно там, където определени области не са обхванати от правила - „празните места“ в правописа (т. нар. некодифицирани случаи), както и при отделни случаи, които могат да се разглеждат като резултат от преходно състояние в процеса на езиковата промяна и които могат да се определят по-скоро като прояви на езиковата несистемност, характерна за книжовната норма (особено при дублетността), а не като проблем на правописните правила или на някакъв съществуващ конфликт между тях.

Всъщност обстоятелството, че най-голямата част от потребителските запитвания към Службата за езикови справки и консултации се отнася тъкмо до книжовния език и най-вече до правописа, съвсем не е случайно и причините за това обстоятелство могат да се тьрсят в самата специфика на правописната норма, а не в рамките на съществуващата в справочниците кодификация. Принципното различие между правописната норма и езиковите норми, които съществуват обективно, сложността на отношението на правописа с отделните езикови равнища, високата му степен на конвенционалност, строга регламентираност (кодифицираност) и задължителност (императивност), поддържани допълнително от символната функция на книжовния език и от ценностната система на обществото, също водят до колебания и несигурност у носителите на езика и до необходимост от компетентен езиков съвет. Нека да припомним тук и обстоятелството, че посредством установените правописни принципи правописьт експлицира в графична форма всички равнища на езика (включително стилистиката и прагматиката). При това трябва да се има предвид, че самият процес на писане като „привеждане“ на езика от една специфична форма на съществуване - устната, в друга, различна като знакова проява форма - писмената, също създава повод колебанията относно правописа да стоят най-високо в скалата на запитванията (докато въпросите за правоговор например се откриват най-ниско в тази скала). Именно транспонирането на устните изказвания в писмени ${ }^{4}$ създава типични за писмената сфера на общуване комуникативни проблеми.

${ }^{4}$ По-подробно за сыщността на този процес вж. у Vachek 1964, според когото трудности възникват тогава, когато устройствата на двете норми - писмената и устната, са отдалечени едно от друго и сумата от съответствията между тях се оказва твърде сложна. Пример за сложен преход между устната и писмената норма може да бъде прилагането на морфологичния принцип в правописа, който води до неизбежни колебания и запитвания относно писменото отбелязване на различни морфеми, напр. обезпечавам или обеспечавам, нараствам или нарасвам и др. под. (по-конкретно за този тип въпроси вж. Томов/Tomov 2006). 
Както се вижда, въпросьт опира освен всичко друго и до функциите и принципните възможности на правописния речник като справочник с нормативен статут, който не е в състояние (а и не това е неговата задача) да регламентира самия избор, да речем, на употреба на дума (съответно слято писане) или словосъчетание (съответно разделно писане) в изречението, защото този избор зависи единствено от намерението на автора на текста да акцентира върху единия или върху другия смисъл според целта на изказването си, след което избраният вариант получава съответния графичен израз в писмения текст. Задаващите въпроси обаче трудно осъзнават, че правописните правила не изключват възможността за факултативни употреби, и не са в състояние да направят разлика между правописно правило и възможен начин на изписване. До допълнително чувство за проблем при справка в правописния речник води и принципното обстоятелство, че неговият словник не обхваща единици с разделно писане (словосъчетания), а само графични думи ${ }^{5}$, от които пишещият сам изгражда словосъчетания, изречения и т.н. според съществуващите езикови правила (неслучайно и не случайно, леснопреносим и лесно преносим, накрая и на края, безкрай и без край, безброй и без брой, на път и напът и под.). В този случай решаващо значение за адекватния избор на съответния вариант има степента на владеене на изразните средства на езика, т.е. езиковата компетентност на автора на текста. Освен това в словника (особено при книжните издания) не е възможно да се регистрират своевременно нововъзникващите сложни думи и изобщо неологизмите. Ще добавим към всичко това, че по принцип правописният речник не дава и стилистични указания, тъй като той не кодифицира съвременната употреба на думите, а само правилното им писане.

Търсещите езикова консултация често не са в състояние да решат категорично дали дадена дума, която е представена в речника като съществително нарицателно име, запазва същия този статут в конкретен текст и дали в определени съчетания тя може да се пише с главна буква (напр. Общзина и общинна, Възраждане и възраждане, средновековна България или Средновековна България). Словникът на правописния речник не може да разреши и това колебание, тъй като в него се съдържат само съществителни нарицателни имена. Всичко това от своя страна също води до потребност от езикова консултация, като в подобни случаи възникналият въпрос често затруднява не само потребителите, а и специалистите от Службата за езикови справки, от които в крайна сметка се очаква разрешение на проблема. От друга страна, непрекъснатите процеси на проприализация и депроприализация в лексиката са и ще продължават да бъдат постоянен източник на нови случаи на правописни колебания в областта на употребата на главни и малки букви.

5 Тук по принцип включваме и глаголите със се или ми се, при които съставните компоненти се приемат за част от словоформата, която от своя страна надхвърля границите на графичната дума, напр. усмихвам се (няма усмихвам). 
Проблем пред носителите на езика като автори на текстове може да се окажат и формулировките на отделни правила и използваната в тях езиковедска терминология, която в наличните справочници не е специално изяснена за по-широкия кръг потребители. При недостатъчна езикова компетентност у потребителите обаче (за това вж. по-долу) дори и най-еднородните и последователните, прецизно формулирани и добре илюстрирани правила не могат да предотвратят възникването на несигурност при прилагането им.

Въз основа на всичко това може да се предположи, че колкото и качествени справочници да съществуват, колкото и подробни и изчерпателни да са правописните правила в тях и колкото и да се усъвършенства кодификацията на правописната норма, при наличието и на най-качественото езиково консултиране у носителите на езика ще продължи да съществува едно относително постоянно естествено съзнание за езиков или правописен проблем и съответно потребност от специализирана езиковедска помощ. От значение тук е и фактът, че езикът, както е известно, е органична част от човешката природа, съзнание и поведение, от творческата същност на човека и както е подчертавано неведнъж от видни езиковеди, той представлява система от краен брой правила в безкраен брой комбинации или краен брой средства с безкрайни възможности за употреби.

\section{3. Противоречива информация в сыществуващите езикови справочници и други източници}

Един от директните поводи за задаване на въпроси към Службата за езикови справки и консултации е противоречието между съществуващите източници на езикова информация. Потребителите по най-различни причини ползват различни справочници, а и имат правото и свободата да избират даден речник за разрешаване на възникналото езиково затруднение. Често посочван проблем пред дежурните езиковеди е, че след направена справка в даден източник се остава с чувството, че е получена неточна или погрешна информация. Посочени са например следните разминавания обезкървявам (ОПР) и обезкръвявам (РБЕ), кавърма (ОПР) и каварма (РБЕ), умисъл - мъжки род (ОПР и РБЕ електр. версия), умисъл - мъжки и женски род (БТР) и умисъл - женски род (СТРБЕ), дебат - само в мн. ч. (РБЕ) и дебат, дебати (ОПР), студио - мн. няма (РБЕ онлайн версия) и студио, студиа (ОПР); нанагорнище (ОПР) и нагорнище и нанагорнище (НПР и $\mathrm{PБЕ);} \mathrm{средноаритметичен} \mathrm{(ОПР)} \mathrm{и} \mathrm{средно} \mathrm{аритметичен}$ (число) (ФМТЕ) и др.под. Нерядко се съобщава за съществуване на разминаване между информацията в учебниците по български език за средното училище и езиковите справочници и граматиките (на първо място Офиџиалния правописен речник).

В някои случаи се поставя трудният и деликатен за разрешаване проблем с т. нар. паралелна кодификация (напр. съществуващото Междуинституционално ръководство за изготвяне на публикациите в ЕС, Наредбата за транскрипция, 
както и някои други нормативни актове, уреждащи езикова материя). От този проблем са засегнати най-вече административните служители, от които се очаква да създават текстове в съгласие с официалната кодификация (посоченият императив се експлицира в почти всички техни запитвания). Паралелната кодификация затруднява работата на административните служители и усложнява междуинституционалната комуникация, особено когато езиковата и правната кодификация в някои случаи не съвпадат. Така у потребителите възниква несигурност в кой случай на коя кодификация да се даде предимство (Бих искала да разбера мнението Ви по един казус, който силно ме смущава. Според Междуинституцчионалното ръководство за изготвяне на публикациите „когато се използва словосъчетанието дали - или не, не се поставя запетая пред или: Независимо дали вносът е деклариран с произход от Малайзия или не ". Наистина ли е регламентирано такова изключение?). В такива ситуации консултиращият езиковед трябва да съумее да приведе адекватни аргументи за едното или другото решение, като се съобразява с вида и правния статут на документа източник.

Като източници на несигурна или противоречива информация се посочват и различни непрофесионални интернет сайтове за езикови консултации, Българските държавни стандарти, Търговският регистър (като източник на официална информация за имена на юридически лица), указатели, наредби, инструкции от институциите на държавната власт и др.под.

\section{4. Несъответствие между кодифицирана норма и езикова практика (узус)}

Тук става въпрос за един езиков феномен, осъзнаван от задаващите въпроси в Службата за езикови справки и консултации: кодифицираните езикови норми в отделни случаи показват явно несъответствие с езиковата практика ${ }^{6}$. Потребителите обръщат внимание на несъответствието на справочниците с узуса, като посочваните източници за подобни разминавания могат да бъдат текстове както от официалната, така и от неофициалната комуникация - институционални документи, форуми в интернет, художествената литература и т.н. Интересно

${ }^{6}$ Срв. особено при деветте норми в динамика, избрани за обект на проучване в рамките на проекта „Изследване на обществените нагласи и ценностните ориентации към българския книжовен език като фактор при кодификацията на нормите му“: правилото за членуване с пълен и кратьк член, формите на местоименията кого, когото, някого, никого, окончанията за 1. л. мн.ч. на глаголите от 1. и 2. спрежение (четем срещу неправилното четеме), правилата за употреба на възвратното притежателно местоимение и на деепричастието, употребата на главни букви при съставни собствени имена, правилата, свързани с учтивата форма - сьгласуване и употреба на главна буква, правилото за употреба на бройната форма, ятовият преглас при причастията (живял - живели срещу неправилната употреба живяли) (Нагласи/Naglasi 2019: Прил. 1). 
е да се отбележи, че диалектни колебания не се експлицират от потребителите като причина за искане на езикови справки, което показва съзнанието на носителите на езика за автономния и наддиалектен характер на книжовния език (въпроси за думи като ма̀сло или масло̀ всъщност засягат варианти, които са били или понастоящем са съставни елементи на книжовната норма). Добре известен факт от теорията на книжовните езици е, че несъответствието между кодифицираната норма и реалната езикова практика е един практически неразрешим езиков конфликт (породен от напрежението между езиковата динамика и статичността на кодификацията) и естествен феномен дори и в рамките на развития книжовен език, а това означава, че този конфликт ще продължава да предизвиква колебания и чувство на несигурност у носителите на езика, което води до потребност от езикови консултации.

\section{5. Липса на достатъчни лингвистичнотеоретични и терминологични познания}

Понякога обаждащите се търсят съвет от Службата за езикови справки и консултации, когато са осъзнали, че не могат да разчитат достатъчно на собствената си езикова компетентност дори при наличието на отлични професионални знания и умения в дадена област (Като използвам случая да се извиня за своята некомпетентност, благодаря за коректния и изчерпателен отговор, който значително улеснява работата ми!). Някои от потребителите разполагат с езикови (правописни или граматични) познания, но пък не разполагат с нужната терминологична компетентност, което също затруднява прилагането на езиковите правила. Така например причините за затрудненията при употребата на запетая често се коренят в липсващите познания по синтаксис и оттам в невъзможността за адекватен анализ и идентифициране на изреченските структури. Затрудненията при употребата на главна и малка буква често са породени от липсващите познания относно това какво представлява собственото име и от ограничените възможности да се определи дали дадена дума или израз е употребен като собствено име в определен контекст, или не, тъй като при голяма част от запитванията за главни и малки букви начинът на писане е недвусмислено зависещ именно от контекста (срв. напр. Прокуратурата или прокуратурата; Комисията или комисията; според европейска/Европейска директива за...; ... в Ритуалната/ритуалната зала; Северен полюс или северен полюс; тази година Оскарът/оскарът трябва да бъде литературен; Разбрах, че Слънцето/ сльнцето е изградено предимно от водород), т.е. правописните проблеми тук са резултат от невъзможността да се разреши във всеки конкретен случай омонимията между собственото и нарицателното име, свързана с употребата му в определена комуникативна ситуация. Така една значителна област от употребата на главни и малки букви, отнасяща се до възможността за дефинирането на собственото име и за графичното му оформяне, се превръща в източник на колебание и в повод за езикови въпроси (други случаи на колебания при глав- 
ните букви са например: Защо Руско-турска война е с една главна буква, а Доростоло-Червенска епархия - с две?).

Критерият за зависимостта на начина на писане от контекста се проявява в засилена степен и при слятото и разделното писане. Като затрудняващи тук се очертават случаите, в които един и същ лексикален състав може да представлява едновременно основи на сложна дума и синтактично съчетание: леснопреносим и лесно преносим, високопоставен и високо поставен, неслучайно и не случайно; оттук и от тук, затова и за това и др.

С непознаването на степента на адаптация (както, разбира се, и със самата степен на адаптация в езика изобщо) на чуждите думи в българския език може да се обяснят въпросите за техните правилни форми, напр. билбордове или билборди, а защо тогава не лаптопове; евро или евра за мн.ч.; Какво е множественото число на думите „демо“ "и „, подкаст“?

\section{6. Неумение за избор между няколко налични възможности за изразяване}

Службата за езикови справки и консултации често е търсена тогава, когато носителят на езика се намира в ситуация, в която има възможност за избор между паралелно съществуващи в езика изразни средства (варианти, иновации) и когато не е сигурен коя от намиращите се на разположение възможности трябва да избере. Възникването на колебания в този случай е свързано с наличието на съвместно съществуващи варианти, обикновено резултат от преходни фази в езиковото развитие. Това поражда осъзната потребност от езикова консултация, чрез която проблемът да бъде разрешен с помощта на компетентно лице. Често обект на запитвания са явления, при които кодификацията чрез инструмента на дублетността е допуснала в книжовна употреба повече от една форма (напр. при форми за множествено число на отделни думи), но трябва да се отбележи също, че значителни колебания възникват и при наличие на конкуренция между кодифицирани и некодифицирани форми и структури, резултат от естествените актуални процеси на преустройство в езиковата система (срв. кого формите или т. нар. мекане като резултат от непрекъснатата динамика на книжовноезиковите норми, обусловена от проникването на елементи от устната реч в писмения език). Езиковото колебание във втория случай се подсилва именно от факта, че алтернативният вариант не е кодифициран, а по отношение на правописната норма, която е формулирана чрез прескриптивни правила, това е решаващо за избора, тъй като при нея границите на възможното са абсолютно категорични и свободният избор е фактически невъзможен. Като случаи на колебания могат да бъдат определени различни начини на писане по стария или по новия правопис (олук или улук), наличието на синоними в езика, респ. подобни по форма лексикални единици, маскулинизациите (рибар или риболовеи, компетенция или компетентност, колега или колежка за назоваване на лице жена), оказионални образувания или новообразувания, които още не са лексикализирани. 
Проблем при последния случай се оказва конкуренцията в езиковата система, извънсистемността на езиковата единица, различни мними аналогии и т.н. (npaхосмуча или прахосмукирам, импрегнатор или импрегнант; Има ли дума „избежен“, след като има ,неизбежен“?; Замуо има „след обяд “ и „, следобед “, а има само „,до обяд“, „,без дообед"?; Замо думата „хора“ няма форма за ед.ч. „хор“"? Искам да попитам, ако е прието да се казва „разкрачвам се“, то какъв глагол се използва за ръце - „разръчвам се“? Има ли дума в българския език, която да опише разтварянето на ръие? За този комплекс от запитвания няма езиковокритични подбуди (специално за тях вж. по-долу), а по-скоро мотивите тук са да се придобие сигурност по отношение на евентуално възможни, но несъществуващи или още нестандартизирани употреби.

\section{7. Липса на умение за ориентация във функционалните стилове на езика и в разликата между устната и писмената форма на езика}

Наред с гореспоменатата липса на достатьчно лингвистичнотеоретични и терминологични познания и неумението за избор между няколко налични възможности за изразяване мотив за търсене на специализирана езиковедска помощ може да бъде и липсата на умение у носителя на езика за ориентация във функционалните езикови стилове и в разликата между устната и писмената езикова проява (мен или мене, отпуска или отпуск; Коя дума е книжовна - събор или сбор, когато се има предвид селищен празник с народни веселия?; Правилно ли е да се употребява думата ,лекарка“?; В болничен лист, когато става дума за жена, в женски или в мъжки род трябва да бъде написано името на професията ѝ- „учител“ “или „учителка“?; Може ли да се каже „Тя е женена за... “?; Кой от глаголите е книжовен и кой е разговорен: „изтьрвам“ или „изтьрвавам“"?; Трябва ли да се пишат с главна буква дльжностите в информаџионен текст (съобши министьр-председателят)?; В художествената литература трябва ли местоименията за учтивост да се пишат с главна буква?; Трябва ли съществителното в израза „Боли ме фарът“ да бъде написано с пълен член, след като изразът е жаргонен? Както се вижда от примерите, трудности и комуникативни проблеми възникват и при транспонирането на устната комуникация в писмена.

Отделни колебания, подбуждащи към търсене на специализирана езиковедска помощ, произтичат и от тясната връзка между специалните езици и общоупотребимия език - предимно в областта на лексиката, която води до проблеми в комуникацията (Коя е правилната дума: , натраплив“ или ,,натрапчив? “). Именно непрекъснатите процеси на терминологизация и детерминологизация с преходни фази на съвместно съществуващи възможности за употреби водят до смущения и несигурност в езиковата практика, като понякога се създават комуникативни или информационни проблеми. 


\section{8. Желание за верифициране и актуализиране на езиковите познания}

Мотив, който може да се прецени като косвено свързан с несигурността и колебанието на говорещите в езиковата практика, е необходимостта от сверка на езиковите познания. Потребителите се обрьщат към Службата за езикови справки, за да си припомнят стари, усвоени преди време знания, да се информират за нововъведени правила или за промени в нормата и кодификацията изобщо (напр. онаследявам или унаследявам; Названията на длъжностите, напр. „изпълнителен директор“", „председател“", с главна или с малка буква се пишат? Има ли промяна в правилото за главната буква при учтивост?). Конкретен повод за това може да бъде чутото от радиото или видяното по телевизията, в което потребителите са забелязали езикова особеност или грешка. В други случаи от ученическите години на търсещия информация е изминало дълго време и той се интересува дали правилата, които някога са изучавани в училище, все още важат. Обажданията често съдържат обяснения, извинения или оправдания (Завършил съм отдавна и съм забравил как беше...; Аз съм от по-старото поколение и нас в училище са ни учили, че е правилно ,зашищавам“ и под).

Във връзка с тази потребност от информация е важно да се спомене и това, че стремежът на говорещите към подобряване на собствената реч е позитивно явление, свързано със заинтересоваността към езика като цяло, което е признак за осъзнаване на важността от едно нормосъобразно и култивирано езиково изказване, като свидетелства и за това, че голяма част от хората съвсем не са безразлични към езиковите въпроси (вж. и по-долу). Понякога обаче се проявява крайно консервативно отношение към езика, изразяващо се в негативност към промените, на които потребителите се натькват в по-късна възраст.

Към разглежданата група мотиви можем да отнесем запитванията за отговори при решаване на задачи от езикови тестове, от ученически домашни работи или при други ученически задания, както и обажданията за разясняване на материал от учебниците по български език (обикновено по такива поводи се обаждат родителите на учениците): Детето е било на олимпиада и е писало преразказ по „Ян Бибиян“, написало е „най-обичам“ - правилно ли е така?; Провокирана днес от чутото по време на онлайн час на дъщеря ми, бих искала да Ви попитам може ли да се пренася на нов ред думата ,игра“?

Не можем да не отбележим и един друг мотив, който се проявява циклично - да се проверят резултатите от националното външно оценяване след 7. клас и от дьржавните зрелостни изпити след 12 . клас.

\section{9. Разрешаване на езиков спор или казус}

Понякога езиковите проблеми водят и до възникване на спорове в личен кръг или в професионална среда с колеги или с началник, напр. Във връзка $c$ възникнал спор относно „как се пише... “ искам да Ви попитам как се пише пра- 
вилно: „военно формирование - 54200 “ или „, Военно формирование - 54200 “; Здравейте, в редакцията на текст имаме разногласие с колеги...

В някои случаи спорещите се хващат на бас и се обзалагат, преди да потърсят контакт със Службата за езикови справки и консултации, за да получат професионално разрешение на спора: Много ви благодаря! Вторият вариант е моят, сега щзе трябва да го защчитя.

Към разрешаването на езикови казуси трябва да причислим още и случаите, в които се иска официално (институционално) становище или посочване на официален източник на информация: Моля да насочите към официален източник, в който се посочва, че правилното изписване на „Венесуела “ е със „с“ (не c „u“"); Ако бащата се казва Михаил, как трябва да бъде записано презимето на детето: Михаилов или Михайлов? Имах нужда от Вашето мнение, за да зашитя малката буква в книга, по която работих. За жалост обаче, издателите са решили да се допитат до нечие некомпетентно мнение и книгата щче излезе с неправилно изписано заглавие.

\section{0. Професионална мотивираност на выпросите}

Очевиден от практиката на езиковото консултиране факт е, че голяма част от въпросите е мотивирана от пряката професионална дейност на потребителите. Това важи освен за телефонните обаждания особено много и за запитванията по електронната поща и молбите за официални писмени становища. Проблеми повече при писането и по-малко при говоренето изпитват най-вече представителите на професиите с висока „езикова интензивност“ - редактори, коректори, преводачи, журналисти, преподаватели, автори на реклами, като тук непременно трябва да се изтькне естествената мотивация за търсене на помощ на административните служители, които се обръщат към Службата за езикови справки и консултации, за да зададат въпроси, възникнали в рамките на професионалната им дейност, или да отправят директна молба за помощ при изготвяне или редактиране на документи.

Като явен фактор, въздействащ върху мотивацията за търсене на специализирана езиковедска помощ, тук трябва да се отбележи и усложняването на писмената комуникация като цяло, което води до повишаване на изискванията за качествено графично оформяне на текстове от всякакъв вид (молби за работа, рекламни и информационни материали, бизнес кореспонденция, нормативни актове, научни съчинения и др.). Количественото нарастване на продуцираните текстове също логически води до появата на множество колебания и въпроси в езиковата практика: Аз съм психолог. В последно време някои колеги подменят „,психологически“ и ,психичен“ с „психологичен“, като се аргументтрат с идеята, че наставката -ски е русизъм. Според мен невинаги е така, напр. „практичен“ и „практически“ не са синоними. Въпросът ми е: как е правилно - „психологически“ или „,психологичен“, напр. „, пихологическата наука“ или „психологичната наука“?; Моля за информация относно правописа на 
текст върху информационна табелка за архив; Пиша Ви във връзка с изготвяне на документ на български език с превод на английски и на френски език, предназначен за канадските власти. В тази връзка ще ви бъда благодарна, ако можете да ми отговорите на следните въпроси...; Царевична или царевично панини - за текст със съдържание на продукт.

Въпрос може да възникне, както видяхме и по-горе, при езиков спор с колеги, но и при направена забележка от началник. Като особено деликатна може да се определи обратната ситуация - когато служител е открил грешка в текст на висшестоящ в административната йерархия, тази грешка непременно трябва да се верифицира като такава от компетентно лице, за да бъде поставена на разглеждане, без да се накърни авторитетьт на висшестоящия, като се запазят добрите служебни отношения (Директорката на училището е решила, че има дума ,вработвам“ и че се пише по този начин).

\section{1. Любопитство към езика}

Една част от телефонните обаждания и имейлите в Службата за езикови справки и консултации идва от потребители, които като цяло се интересуват от езика и проявяват любопитство и любознателност към него. За разлика от гореописания случай, тук въпросите са мотивирани по-скоро от личен интерес и нерядко от патриотични чувства. Мотивът за обаждането може да се състои в това, че се осъзнават проявите на езиковите промени - обаждащите се се натькват на езикови феномени, за които имат въпроси и които е необходимо да се разяснят по-подробно. При втората група интересуващите се от генеалогията например биха искали да получат информация за произхода на техните фамилни имена, а краеведи - за имена на географски или топографски обекти от родния край. Въпроси от този вид могат да се тълкуват като безоценъчни (тук спадат напр. въпросите за произход на думи, напр. Бихте ли ми казали кой е коренът на думата „гарван“ и същзо така дали думите „гарван“ и ,гарга“ имат общ, корен?; Колко думи има в българския език?, въпросите, свързани със старобългарските азбуки, като Коя е буквата от глаголицата, която е еквивалентна на днешната буква Я?; Интересувам се как е правилно да се изпише „България“ със символите на глаголицата; Каква писменост са използвали старите българи преди кирилицата и глаголицата и преди руните и под.).

\section{2. Желание за изразяване на критични мнения}

Службата за езикови справки и консултации получава обаждания и писма, които не съдържат конкретни въпроси, а са породени от желание за коментар и споделяне на критично мнение със специалистите езиковеди във връзка със състоянието на езика. За разлика от по-горе разгледаните обаждания, предизвикани от любопитство към езика, в този случай се поставят дискусионни въпроси или се изказват определени мнения или становища, които 
са придружени с оценки, обикновено негативни, породени най-често от едно по-тясно и рестриктивно разбиране за книжовната норма и почиващи на романтично или емоционално отношение към езика или на ценностни нагласи към него. Потребителите използват възможността да получат потвърждение за собственото си критично становище за нещата. Обект на езикова критика в областта на правописа например е недостатьчното владеене на правописните правила (посочват се различните правописни грешки), прекаленото използване на главни букви при съставни собствени имена, както и ,злоупотребата“ с латиница в писмената практика. Езиковата критика е насочена често и към употребата на чужди думи вместо българските им еквиваленти, към езика на младото поколение (Младите хора не могат да пишат!) и особено често към езика на медиите и на политиците, към езика на рекламите, както и към неграмотността като цяло (Всеки си говори както си иска!). В такива случаи често се апелира към отговорността на езиковедите и дори се предлагат санкции за нарушителите на книжовните норми (въвеждането на т.нар. езикова полиция със съответните правомощия). Многократно се критикува общият упадък на българския език и се изразяват опасения от т. нар. езикова криза (във връзка с това се използват такива отрицателни понятия като обедняване, разруха, замърсяване, оварваряване, опошляване и под. (по-подробно вж. Томов/Tomov 2016). Така Службата за езикови справки и консултации поема функцията на „обществен отдушник“, който да даде простор на гневната обществена реакция, като намали създалото се напрежение. Като конкретни езикови явления, които се критикуват, могат да се посочат накратко изписването на Воскресе от поздрава Христос воскресе с главна буква по телевизията, „при това в най-гледаното телевизионно време“, изписването на Св. Св. (Кирил и Методий) с две главни букви (изразява се възмущение от интернет страницата на Националната библиотека), употребата на маскулинизирани форми - редактор вм. редакторка и под., употребата на специализирани термини (резидирам, диверсификация, сатурация, полимеразен и под. в медиите).

Потребителите използват възможността да проявят загриженост за езика, понякога съпроводена с емоционалност и приповдигнатост: Българската театрална традиция има привилегията да притежава забележителна рецитаторска школа, която в последните десетилетия бе почти напьлно унищожена. В този процес загльхнаха гласовете на знаменити актьори, потьмня бляскавата декламаторска традиция, онемяха дръзките послания на гениални автори, особено твории на достолепна стихотворна реч в стилистиката на високата словесност. През всичките над тридесет години, в които работя със слово пред микрофон и на сцена, скромно и усърдно съм се опитвал да върна художествения изказ на великолепния ни език - безценно духовно наследие, което сме призвани да почетем, опазим и пренесем, за да останем във времето, но и за да пребъде навеки, втъкано в невидимите, горди притежания на ичелия човешки род. 
Специално внимание заслужава поводът за обаждане или кореспонденция със Службата за изразяване на критично отношение към либералността на езиковедите, които се обвиняват в бездействие и пасивност или в конформизъм заради съобразяването на кодификацията с масовата практика, а не строго с езиковата система: Моля да ми поясните Институтьт приема ли, одобрява ли такава употреба, или не, а ако не, то как показва това не пред общество$m о$ [по повод употреба на форми за множествено число при думи с абстрактно значение като политики, практики или за стилистична употреба на такива форми - напр. животи]; ... Смятате ли за достатъчна (по обем и иеленасоченост) иначе отличната по качество просветителска дейност на проф. Брезински и проф. Мурдаров в медиите? Какви евентуално негативни последици би имало за Института, ако периодично (втори въпрос е на колко време) той обявява най-честите и най-грубите правописни грешки?

В представите на част от потребителите езиковедите са длъжни да пазят езиковата чистота и да премахват езиковите недостатьци, както и да разрешават или забраняват употребата на отделни думи или форми (Как така сте решили мн.ч. на ,билборд“ “да бъде „, билбордове“, а на ,лаптоп“ “да не е „лаптопове“, a „лаптопи“ - трудно се обяснява на учениците!; Защо давате „сканирам“, а не „,кенирам“, след като съществителното е „скенер“?; Защо „не доживявам“ не е като „недочувам“; Какво налага смяната на правопис на дадена дума? Защо толкова години се пише по един правилен начин и на някой му щуква, че трябва да се пише по друг начин? Кое налага изобщо промяната в граматиката?). Недоволство обикновено се изразява по отношение на съществуващите дублети.

Зад всички разгледани дотук мотиви обаче като съществен централен изходен пункт стои стремежът на носителите на езика към нормосъобразно изразяване, към правилна езикова употреба, породен от схващането на книжовния език и грамотността като ценност, като средство за повишаване на личния и обществения престиж и белег на висок професионализъм. Важно е да подчертаем, че ценностната рефлексия на книжовния език, проявявана явно или неявно от потребителите на Службата за езикови справки и консултации, напълно се съотнася с резултатите от националното представително проучване на езиковите нагласи и ценностните ориентации към българския книжовния език, осъществено през 2019 г. (подробно вж. Нагласи/Naglasi 2019). В съвременното общество владеенето на книжовната норма все повече се оценява като критерий за социален престиж и белег на висок професионализъм, а езиковата грамотност отчетливо се осмисля като задължително условие за професионална и личностна реализация и успешно общуване. Разширява се крьгът от хора, които в своята професионална дейност се стремят да се придържат към правилата на книжовния език и във връзка с това се обръщат към Службата за езикови справки и консултации, търсейки отговор на различни езикови въпроси. Ниското ниво на езикова грамотност, обратно, се възприема като знак за лошо качество във всяка 
една област. Осъзнава се като цяло и опасността от негативните последствия, произтичащи от неспазването на книжовните норми. Повечето институции на практика поддържат собствени страници и публикуват информационни материали в интернет, с което привличат вниманието върху себе си и строго държат на добрия обществен имидж. Потребителите много често излагат тези съображения експлицитно, най-вече във встъпителната част на въпросите, особено в случаи, когато комуникацията е публична: Ще използвам думата в интернет.

Съзнателно или несъзнателно проявена, във всяко езиково запитване присъства необходимостта от норма, което се изразява от лексемите правилен, правилно (и синонимите им) и съответно от предварителното очакване на еднозначен и категоричен отговор (как е правилно, правилно ли е, дали е правилно, кой е правилният вариант, по-правилно ли е, щзе бъде ли правилно и т.н.). В разрез с естествената потребност на носителите на езика от конкретни правила, от еднозначно и съобразено с нормите изказване (която в повечето случаи се проявява твърде настоятелно) е високата степен на позитивно и либерално отношение към вариантността в книжовния език: дублетите и вариантните възможности за изразяване не са особено добре приемани от потребителите и се предпочита категоричното решение, тоест нещо трябва да бъде или правилно (книжовно), или неправилно (некнижовно). Обществената и индивидуалната потребност от норма е интересен и важен въпрос, който, както се вижда, е тясно свързан с езиковото съзнание и с мотивите за търсене на специализирана езиковедска помощ, но заслужава самостоятелно разглеждане.

$$
* * *
$$

Подробният анализ на електронния корпус от въпроси на Службата за езикови справки и консултации ни позволи да реконструираме, разчетем и опишем разнообразните мотиви за търсене на специализирана езиковедска помощ във връзка с колебанията и трудностите, възникващи в процеса на езиковото общуване. Извършените наблюдения ни дават възможност да направим следните общи изводи.

Част от представените мотиви за задаване на въпроси могат да се определят като собствено прагматични (напр. неумение или нежелание за ползване на справочници поради различни причини), а други като предимно аксиологични (при които се изразява най-вече негативна оценка - отправянето на езикова критика), като в определени случаи мотивите могат да се проявяват и в комбинация (напр. желанието за верифициране и актуализиране на езиковите познания, придружено и с оценка). В повечето от разгледаните мотиви са отразени нагласите и ценностните ориентации на потребителите на Службата към езика, както и очакванията и изискванията на езиковата общност към езиковедите като цяло.

Проучването и описанието на потребителските мотиви допринасят за разкриването и оптимизирането на процеса на общуване между специалистите езиковеди и общността от неспециалисти, както и за подобряването на уменията на членовете на езиковата общност в използването на съществуващите 
традиционни и разработващите се най-нови източници на езикова информация. Същевременно изследването има значение и за разкриването на специфичните потребности на носителите на езика от надеждна професионална информация и е насочено към по-нататьшното разрешаване на въпроса как езикознанието да предава на широката публика по-ефективно резултатите от своята научноизследователска дейност. Всичко това означава, че изучаването и разкриването на потребителските мотиви за търсене на специализирана езиковедска помощ е от изключително голямо значение за теорията и най-вече за практиката на езиковото консултиране като съвременна и най-оперативна форма на езикова култура - както в нейните традиционни, така и в най-модерните ѝ прояви, като езиковото консултиране в онлайн среда, осъществявано чрез разработването на интернет справочника „Езикови справки“.

Описаните мотиви за търсене на специализирана езикова помощ без съмнение очертават и важни изходни позиции за бъдещи сравнителни изследвания: универсални ли са потребностите на тьрсещите специализирана езиковедска помощ, или се влияят от специфични екстралингвистични (национално-културни) фактори, от обществената среда, доколко е съществено това влияние, кое е общото и кое е специфичното и зависи ли то от други фактори; съществуват ли разлики в това отношение между т. нар. малки и големи езици?

Накрая, нека да подчертаем и нещо много съществено: след като приемаме потребителите на Службата за езикови справки и консултации за представителна извадка от активните носители на езика, то с пълно основание можем да твърдим, че мотивите за тьрсене на специализирана езикова помощ показват в най-голяма степен в какви реални комуникативни условия функционира книжовният език, както и важността на осъзнатото нормосъобразно езиково поведение в сферите на култивираната комуникация, представителни за книжовния език. Това са едни от основните проблеми в теорията на езиковата култура, на която се опира езиковото консултиране и в частност методите, които се използват в него.

\section{Съкращения}

БТР - Български тълковен речник (1994)

НПР - Нов правописен речник на българския език (2002)

ОПР - Официален правописен речник на българския език (2012)

РБЕ - Речник на българския език (2001-2015)

СТРБЕ - Съвременен тълковен речник на българския език с приложения (1995)

ФМТЕ - Физико-математическа и техническа енциклопедия (1990-2008) 


\section{Литература}

Димитрова 2005: Димитрова, М. Осъзнати проблеми при книжовноезиковите норми. Български език и литература, № 4, с. 66-69.

Костадинова 1996: Костадинова, П. Бележки за езиковите справки от „Езикови справки“. - В: Езикът на тоталитарното и посттоталитарното общество. София, 1996, 129-133.

Мониторинг 2020: Мониторинг на въпросите в справочника Езикови справки по интернет за периода 2018-2020 г. Ръкопис.

Нагласи 2019: Езиковите нагласи на днешните българи. - Български език. Прил. 1. Езикови нагласи, езиково поведение и кодификацията на книжовните норми днес, 2019; Прил. 2. Езикови нагласи, мотивачия и оценки на езиковата общност за спазването на книжовните правила, 2019.

Паскалев 2006: Паскалев, Н. Социална дистанция, статус и речев етикет. - Български език, № 3, с. 31-36.

Томов 2006: Томов, М. Правописни колебания, отразени във въпросите към Служба „Езикови справки“. - Български език, № 3, с. 10-20.

Томов 2016: Томов, М. Българската реч във фокуса на езиковата критика. - Българска реч, 2016, № 1, 13-17.

Томов 2016а: Томов, М. Въпросите към службата за езикови справки и консултации като източник на информация за съвременната правописна норма и практика. Български език, 2016, № 3, 30-40.

Томов 2017: Томов, М. Езиковата култура в режим на диалог. - В: Доклади от Международната юбилейна конференция на Института за български език ,Проф. Л. Андрейчин “. (София, 15-16 май 2017 г.). Ч. 1. София, Институт за български език, 2017, 43-46.

Томов, Кунева 2018: Томов, М., И. Кунева. Езикови справки по интернет. - Български език и литература, 2018, № 2, 184-190.

Чаралозова, Станчева 2006: Чаралозова, К., Р. Станчева. Проблеми на граматичната норма (върху материал от „Езикови справки“). - Български език, № 3, 21-30.

Чаралозова и др. 2017: Чаралозова, К., М. Томов, Т. Александрова. Справочник „Езикови справки по интернет“. - В: Доклади от Международната юбилейна конференщия на Института за български език „Проф. Л. Андрейчин“. (София, 15-16 май 2017 г.). Ч. 2. София, Институт за български език, 2017, 112-116.

\section{References}

Charalozova, Stancheva 2006: Charalozova, K., R. Stancheva. Problemi na gramatichnata norma (varhu material ot „Ezikovi spravki“) [Problems of the Grammatical Norm (on the Language Consultations Service Material]. - Balgarski ezik, 2006, № 3, 21-30.

Charalozova et al. 2017: Charalozova, K., M. Tomov, T. Aleksandrova. Spravochnik „Ezikovi spravki po internet“" [Handbook Language Consultations over the Internet]. In: Dokladi ot Mezhdunarodnata yubileyna konferentsia na Instituta za balgarski ezik „Prof. L. Andreychin“. (Sofia, 15-16 may 2017 godina). Ch. 2. Sofia, Institut za balgarski ezik, 2017, 112-116.

Dimitrova 2005: Dimitrova, M. Osaznati problemi pri knizhovnoezikovite normi [Realized Problems with the Standard Language Norms]. - Balgarski ezik i literatura, № 4, 66-69. 
Kostadinova 1996: Kostadinova, P. Belezhki za ezikovite spravki ot „Ezikovi spravki“ [Notes on Language Consultations from the Language Consultations Service]. - In: Ezikat na totalitarnoto i posttotalitarnoto obshtestvo. Sofia, 1996, 129-133.

Monitoring 2020: Monitoring na vaprosite v spravochnika Ezikovi spravki po internet za perioda 2018-2020 г. [Monitoring of the questions in the handbook Language Consultations over the Internet for the period 2018-2020]. Rakopis.

Naglasi 2019: Ezikovite naglasi na dneshnite balgari [Language Attitudes of Bulgarians Today]. - Balgarski ezik. Suppl. 1. Ezikovi naglasi, ezikovo povedenie i kodifikatsiyata na knizhovnite normi dnes [Language Attitudes, Linguistic Conduct and Codification of Standard Language Norms Today], 2019; Suppl. 2. Ezikovi naglasi, motivatsia i otsenki na ezikovata obshtnost za spazvaneto na knizhovnite pravila [Language Attitudes, Languuage Community Motivation and Evaluation for Adhering to the Standard Language Norms], 2019.

Paskalev 2006: Paskalev, N. Sotsialna distantsia, status i rechev etiket [Social Distance, Status and Linguistic Etiquette]. - Balgarski ezik, 2006, № 3, 31-36.

Tomov 2006: Tomov, M. Pravopisni kolebania, otrazeni vav vaprosite kam Sluzhba „Ezikovi spravki“ [Orthographic Hesitations Reflected in the Questions to the Service for Language Consultations]. - Balgarski ezik, № 3, 10-20.

Tomov 2016: Tomov, M. Balgarskata rech vav fokusa na ezikovata kritika [Bulgarian speech in the focus of language criticism]. - Balgarska rech, 2016, № 1, 13-17.

Tomov 2016a: Tomov, M. Vaprosite kam sluzhbata za ezikovi spravki i konsultatsii kato iztochnik na informatsia za savremennata pravopisna norma i praktika [Questions to the Language Consultation Service as a Source of Information about the Modern Spelling Norm and Practice]. - Balgarski ezik, 2016, № 3, 30-40.

Tomov 2017: Tomov, M. Ezikovata kultura v rezhim na dialog [Language Cultivation in Dialogue Mode]. - In: Dokladi ot Mezhdunarodnata yubileyna konferentsia na Instituta za balgarski ezik „Prof. L. Andreychin“. (Sofia, 15-16 may 2017 godina). Ch. 1. Sofia, Institut za balgarski ezik, 2017, 43-46.

Tomov, Kuneva 2018: Tomov, M., I. Kuneva. Ezikovi spravki po internet [Language Consultations over the Internet]. - In: Balgarski ezik i literatura, 2018, № 2, 184-190.

Vachek 1964: Vachek, J. Zum Problem der geschriebenen Sprache. - In: A Prague School Reader in Linguistics. Bloomington, Indiana University Press, 441-452.

Доц. д-р Милен Томов

Секция за съвременен български език

Институт за български език „Проф. Любомир Андрейчин“

Българска академия на науките

Бул. „Шипченски проход“ 52, бл. 17

1113 София, България

tomovm@ibl.bas.bg

Assoc. Prof. Milen Tomov, PhD

Department for Modern Bulgarian Language

Institute for Bulgarian Language „Prof. Lyubomir Andreychin“

Bulgarian Academy of Sciences

52 Shipchenski prohod Blvd., bl. 17

Sofia 1113, Bulgaria

tomovm@ibl.bas.bg 